\title{
Swimming ability and behavior of Mrigal carp Cirrhinus mrigala and application to fishway design
}

\author{
Lu Cai ${ }^{1}$, Yiqun Hou' ${ }^{1}$ David Johnson ${ }^{1,2}$, Ping Zhao' ${ }^{1}$, Peng Zhang ${ }^{1,3, *}$ \\ ${ }^{1}$ Key Laboratory of Ecological Impacts of Hydraulic-Projects and Restoration of Aquatic Ecosystem of Ministry of Water \\ Resources, Institute of Hydroecology, Ministry of Water Resources and Chinese Academy of Sciences, Wuhan 430079, PR China \\ ${ }^{2}$ School of Natural Sciences and Mathematics, Ferrum College, Ferrum, VA 24088, USA \\ ${ }^{3}$ State Key Laboratory of Water Resources and Hydropower Engineering Science, Wuhan University, Wuhan 430072, PR China
}

\begin{abstract}
To mitigate the impact of river fragmentation on fish resulting from dams, specifically the fragmentation of Indian rivers, the design and construction of high-efficiency fishways is important. Information on fish swimming ability and behavior is necessary to develop design criteria for the target species, Cirrhinus mrigala, a cyprinid native to India, Pakistan and Bangladesh. Swimming ability and behavior data for the genus are limited. To augment existing information, the swimming ability and behavior of juvenile C. mrigala were investigated by determining their induced flow velocity $\left(U_{\text {ind }}\right)$, critical swimming speed $\left(U_{\text {crit }}\right)$, and burst speed ( $\left.U_{\text {burst }}\right)$ in a swimming respirometer. To facilitate application to fishway design, swimming assessment data were converted to a cumulative response; for $U_{\text {ind }}$ it is the cumulative percentage of fish swimming against the current at a given velocity, and for $U_{\text {crit }}$ and $U_{\text {burst, }}$ it is the percentage of fish able to maintain a given velocity for the specified time interval without fatigue. Results include 2 primary findings. (1) The cumulative response velocity (\%) of fish induced to swim, or reach fatigue, increased with flow velocity. The cumulative velocity is useful for developing fishway design criteria. (2) The mean values of $U_{\text {ind }} U_{\text {crit }}$ and $U_{\text {burst }}$ were $0.427 \pm 0.013,2.768 \pm 0.146$ and $3.493 \pm 0.121$ body lengths ${ }^{-1}( \pm \mathrm{SE})$. The values of $U_{\text {crit }}$ and $U_{\text {burst }}$ indicate that the swimming ability of C. mrigala is relatively low for a cyprinid.
\end{abstract}

KEY WORDS: Flow velocity $\cdot$ Induction $\cdot$ Fatigue $\cdot$ Swimming performance

\section{INTRODUCTION}

Fish swimming ability and behavior are important for feeding, predator avoidance, seeking refuge and migration (Domenici \& Kapoor 2010). Based on experimental tests of velocity and time to exhaustion, swimming modes are classified as sustained, prolonged and burst (Brett 1964). Information on swimming ability and behavior is important for setting design criteria for fishways (Katopodis \& Williams 2012) and predicting the selectivity and efficiency of capture in trawl nets (Winger et al. 1999). When discussing trends in fishway science, engineering and practice, Silva et al. (2018) acknowledged the impor-

${ }^{*}$ Corresponding author: zhang860214@foxmail.com tance of integrating all relevant scientific knowledge (i.e. fish biology and ecohydraulic analysis), as well as the need for adaptive management. The importance of considering fish biology (particularly swimming ability and behavior) in fishway design has been recognized internationally for over a century, but little data is available for species other than salmon (Katopodis 2005, Williams et al. 2012). While abundant data on swimming ability and behavior of fishes has been gathered in developed countries, information is more limited in developing countries, including China and India.

Mrigal carp Cirrhinus mrigala is a species of Cyprinidae found in India, Pakistan and Bangladesh and is

() The authors 2018. Open Access under Creative Commons by Attribution Licence. Use, distribution and reproduction are unrestricted. Authors and original publication must be credited. 
one of the major Indian carp in terms of abundance and commercial value (Ahmed \& Khan 2004). It has been introduced into other parts of India and adjacent countries, including China in 1982. It is a bottom feeder, subsisting primarily on decaying vegetation. It attains a length of $99 \mathrm{~cm}$ and weight of $12.7 \mathrm{~kg}$ (Talwar \& Jhingran 1991). Research related to aquaculture, toxicology and biochemistry has been carried out (Palaniappan \& Karthikeyan 2009, Nigam et al. 2017, Kumar et al. 2018), but information on behavior, including movement, is limited.

To mitigate the impact of river fragmentation resulting from the construction of dams, specifically on Indian rivers (Grumbine \& Pandit 2013, Grill et al. 2015), high-efficiency fishways have been constructed. Das \& Hassan (2008) and Ravichandran \& Semwal (2016) concluded that the absence of data on fish swimming ability and behavior has resulted in unsuccessful fishways in India.

This study provides data on the swimming ability and behavior of juvenile C. mrigala to help improve fishway design. Swimming was assessed by measuring induced flow velocity ( $U_{\text {indi }}$ the lowest water velocity that induces continuous swimming against the current), critical swimming speed ( $U_{\text {criti }}$ the maximum swimming speed that can be maintained for a $15 \mathrm{~min}$ time interval) and burst speed ( $U_{\text {bursti }}$ the maximum swimming speed that can be maintained for a $1 \mathrm{~min}$ time interval). These swim test parameters were used to develop flow velocity criteria (minimum flow velocity, attractive flow velocity and maximum flow velocity) for a fishway design that is optimal for C. mrigala.

\section{MATERIALS AND METHODS}

\section{Fish and equipment}

Approximately 100 juvenile Cirrhinus mrigala were obtained from an aquaculture operation in Lushan City $\left(29^{\circ} 42^{\prime} \mathrm{N}, 116^{\circ} 26^{\prime} \mathrm{E}\right)$, China. The fish were maintained for $1 \mathrm{wk}$ in holding tanks with dechlorinated, fully aerated tap water at ambient temperature and photoperiod. Healthy fish were randomly selected for testing (mean \pm SE body length: $0.147 \pm 0.001 \mathrm{~m}$; mass: $52.3 \pm 0.7 \mathrm{~g}$ ). Fish were fasted for $24 \mathrm{~h}$ before testing.

Fish were tested in a swimming respirometer (Cai et al. 2014b) with a volume of $95 \mathrm{l}$ and a $28 \mathrm{l}$ rectangular swim chamber $(70 \times 20 \times 20 \mathrm{~cm})$. The respirometer was submerged in a $2501(143 \times 63 \times 28 \mathrm{~cm})$ tank. Normal respirometer operating assumptions were made: swimming speed $(U)$ of the fish equals water flow velocity, as measured with a propeller flow velocity meter (LGY-II). The dissolved oxygen and temperature in the respirometer were monitored with a multi-parameter probe (YSI DO200A). Water temperature varied from 15.9 to $18.7^{\circ} \mathrm{C}$ and dissolved oxygen was $>7.0 \mathrm{mg} \mathrm{l}^{-1}$, maintained by aeration.

\section{Experimental design}

Stepped velocity tests were carried out to measure (1) induced flow velocity $\left(U_{\text {ind }}\right)$, the speed at which a fish is not able to hold station without actively swimming, and (2) critical swimming speed ( $\left.U_{\text {crit }}\right)$ and burst speed $\left(U_{\text {burst }}\right)$, to indicate prolonged and burst swimming capability (Brett 1964).

In the $U_{\text {ind }}$ and $U_{\text {crit }}$ test (10 fish), (1) each fish was tested individually. Fish body length (BL) was measured and the test fish was allowed to adapt to experimental conditions at $0.04 \mathrm{~m} \mathrm{~s}^{-1}$ for $1 \mathrm{~h}$. At the initial flow velocity of $\left(0.04 \mathrm{~m} \mathrm{~s}^{-1}\right)$, the fish was nearly motionless along the flow direction. The water velocity was increased by approximately $0.01 \mathrm{~m} \mathrm{~s}^{-1}$ at $5 \mathrm{~s}$ intervals and, when the fish was no longer able to hold station and began actively swimming, the flow velocity was reported as $U_{\text {ind }}$ (Cai et al. 2018). (2) The flow velocity was then increased to $1.0 \mathrm{BL} \mathrm{s}^{-1}$ and increased by $1.0 \mathrm{BL} \mathrm{s}^{-1}$ at $15 \mathrm{~min}$ intervals (Brett 1964). When the fish ceased swimming, the flow velocity was decreased and the swim chamber was rapped with a plastic stick to encourage the fish to continue swimming. If the fish resumed swimming, the velocity was reset to the velocity at which the fish ceased swimming. A fish was regarded as exhausted when it did not resume swimming and rested against the wire grid for $10 \mathrm{~s}$. When the fish was exhausted, the test was over and body mass was measured.

For the $U_{\text {ind }}$ and $U_{\text {burst }}$ test (10 fish), step (1) was same as above; when swimming was induced, the flow velocity was adjusted to $1.0 \mathrm{BL} \mathrm{s}^{-1}$. The velocity was increased by $1.0 \mathrm{BL} \mathrm{s}^{-1}$ at 1 min intervals (Wang et al. 2017) and when the fish was exhausted, the test was over and body mass was measured.

Among the fish selected for testing, 20\% (4 fish, 2 fish in each test) failed to swim continuously when challenged. When a fish did not perform, the test was interrupted and another fish was selected for testing.

\section{Data analysis}

$U_{\text {crit }}$ (and $U_{\text {burst }}$ ) were calculated according to Eq. (1) (Brett 1964): 


$$
U_{\text {crit }}=U_{p}+\left(t_{f} / t_{i}\right) \times U_{t}
$$

where $U_{p}\left(\mathrm{BL} \mathrm{s}^{-1}\right)$ is the highest velocity at which fish swam for the full time interval, $U_{t}\left(\mathrm{BL} \mathrm{s}^{-1}\right)$ is the speed step, $t_{f}(\min )$ is the time to fatigue during the last velocity step and $t_{i}(\mathrm{~min})$ is the time step.

The dimensionless fish speed $\left(U^{*}\right)$, calculated using Eq. (2), compresses the variation of fish speed with body length, and is useful for comparing swimming performance among fish species of different size (Katopodis \& Gervais 2016):

$$
U^{*}=U / \sqrt{g \times \mathrm{BL}}
$$

where $U\left(\mathrm{~m} \mathrm{~s}^{-1}\right)$ is the absolute fish speed ( $U_{\text {ind }}, U_{\text {crit }}$ or $\left.U_{\text {burst }}\right)$ and $g$ is gravitational acceleration, $9.81 \mathrm{~m} \mathrm{~s}^{-2}$.

The cumulative response velocities (\%) were used to set design criteria for fishway velocities. For $U_{\text {ind }}$, this was the cumulative percentage of fish, at a given velocity, that sensed the current direction and swam against it. With $U_{\text {crit }}$ and $U_{\text {burst, }}$ it was the cumulative percentage of fish that maintained a given swimming velocity for the specified time interval. The percentage (y) induced for $U_{\text {ind }}$ or exhausted for $U_{\text {crit }}$ and $U_{\text {burst }}$ was fit to the flow velocity $(x)$ (i.e. fish swimming speed) using Origin 9.0 (OriginLab), giving Eq. (3):

$$
y=a \mathrm{e}^{-\mathrm{e}^{-b x+c}}
$$

where $a, b$ and $c$ are fitting parameters and $e$ is the natural logarithm base. The velocity $(x)$ at which $y=$ $50 \%$ (the $50 \%$ response rate, a fitted value) is designated as $U_{50}$.

The mean, median and $50^{\text {th }}$ percentile values and their differences were calculated and compared: $D_{\text {mm }}=\left(U_{\text {mean }}-U_{\text {median }}\right) / U_{\text {mean }}$ and $D_{\text {m50 }}=\left(U_{\text {mean }}-\right.$ $\left.U_{50}\right) / U_{\text {mean }}$.

\section{RESULTS}

The percentages of induction and fatigue, in relative $\left(U ; B L ~^{-1}\right)$, absolute $\left(U_{;} \mathrm{m} \mathrm{s}^{-1}\right)$ and dimensionless $\left(U^{*}\right)$ units of velocity all increased with flow velocity (Fig. 1). Fig. 1 also displays the $95 \%$ confidence intervals and $50 \%$ response velocity $\left(U_{50}\right)$ for $U_{\text {ind }}, U_{\text {crit }}$ and $U_{\text {burst. }}$.

The mean, median and $50 \%$ response velocities $U_{\text {ind }}(\mathrm{n}=20), U_{\text {crit }}(\mathrm{n}=10)$ and $U_{\text {burst }}(\mathrm{n}=10)$ expressed in relative $\left(\mathrm{BL} \mathrm{s}^{-1}\right)$, absolute $\left(\mathrm{m} \mathrm{s}^{-1}\right)$ and dimensionless units are given in Table 1, which also includes $D_{\mathrm{mm}}$ and $D_{\mathrm{m} 50}$. The cumulative response velocity of $U_{\text {ind, }} U_{\text {crit }}$ and $U_{\text {burst }}$ in absolute units will be used in the discussion of fishway design, as it is most useful for hydraulic engineers.

\section{DISCUSSION}

\section{Effect of flow velocity on induction and fatigue}

Measures of fish swimming ability and behavior ( $U_{\text {ind, }}, U_{\text {crit, }}$ and $\left.U_{\text {burst }}\right)$ are expressed as means $( \pm \mathrm{SE})$ and the cumulative responses for induced swimming and fatigue versus flow velocity are provided to show the distribution in ability and behavior among test fish. The data could have been set to a linear function, but cumulative response is not linear if the behavior of test organisms is normally distributed (dose-response data from toxicity testing, for example). As expected, fitting cumulative response with flow velocity gave a higher $\mathrm{R}^{2}$ value when fit using an exponential equation (Fig. 1) than when fit using a linear equation, in accord with Brett (1967). Fig. 1 was designed for convenient application by engineers when setting flow criteria for different sections of a fishway for maximal passage.

For example, the minimum fishway velocity for Cirrhinus mrigala could be set at the $80 \%$ response velocity for $U_{\text {ind }}\left(0.070 \mathrm{~m} \mathrm{~s}^{-1}\right)$, rather than at the $50 \%$ response velocity $\left(0.062 \mathrm{~m} \mathrm{~s}^{-1}\right)$ so that a larger fraction of fish avoid disorientation. The maximum flow could be set at the $20 \%$ response for $U_{\text {burst }}(0.401 \mathrm{~m}$ $\mathrm{s}^{-1}$ ), rather than the $50 \%$ response flow velocity $\left(0.488 \mathrm{~m} \mathrm{~s}^{-1}\right)$ so that a larger fraction of fish are able to pass. However, it should be noted that fish swimming ability (especially $U_{\text {burst }}$ ) measured in a flume or a chamber may be slightly lower than in natural waters. Tudorache et al. (2007) found that swim chambers can restrict burst-coast swimming in Cyprinus carpio.

Setting the fishway entrance velocity is not as straightforward. Pavlov (1989) recommended that entrance velocity be set at $0.6-0.8 U_{\text {crit }}$. However, a flow velocity in the range $0.2-0.3 U_{\text {crit }}$ resulted in the best attraction efficiency for the carp Percocypris pingi (L. Cai et al. unpubl. data). This shows clearly that Pavlov's (1989) recommendation is not appropriate for all species. Hence, to recommend the entrance velocity for $C$. mrigala with confidence, investigation of tropism behavior is necessary.

\section{Swimming ability of $C$. mrigala compared to other species}

Swimming ability data for the Cirrhinus genus are limited. Spinibarbus sinensis, Onychostoma sima and C. mrigala are in the Barbinae subfamily of Cyprinidae. For $S$. sinensis and $O$. sima (BL 0.06 0.07 m), 

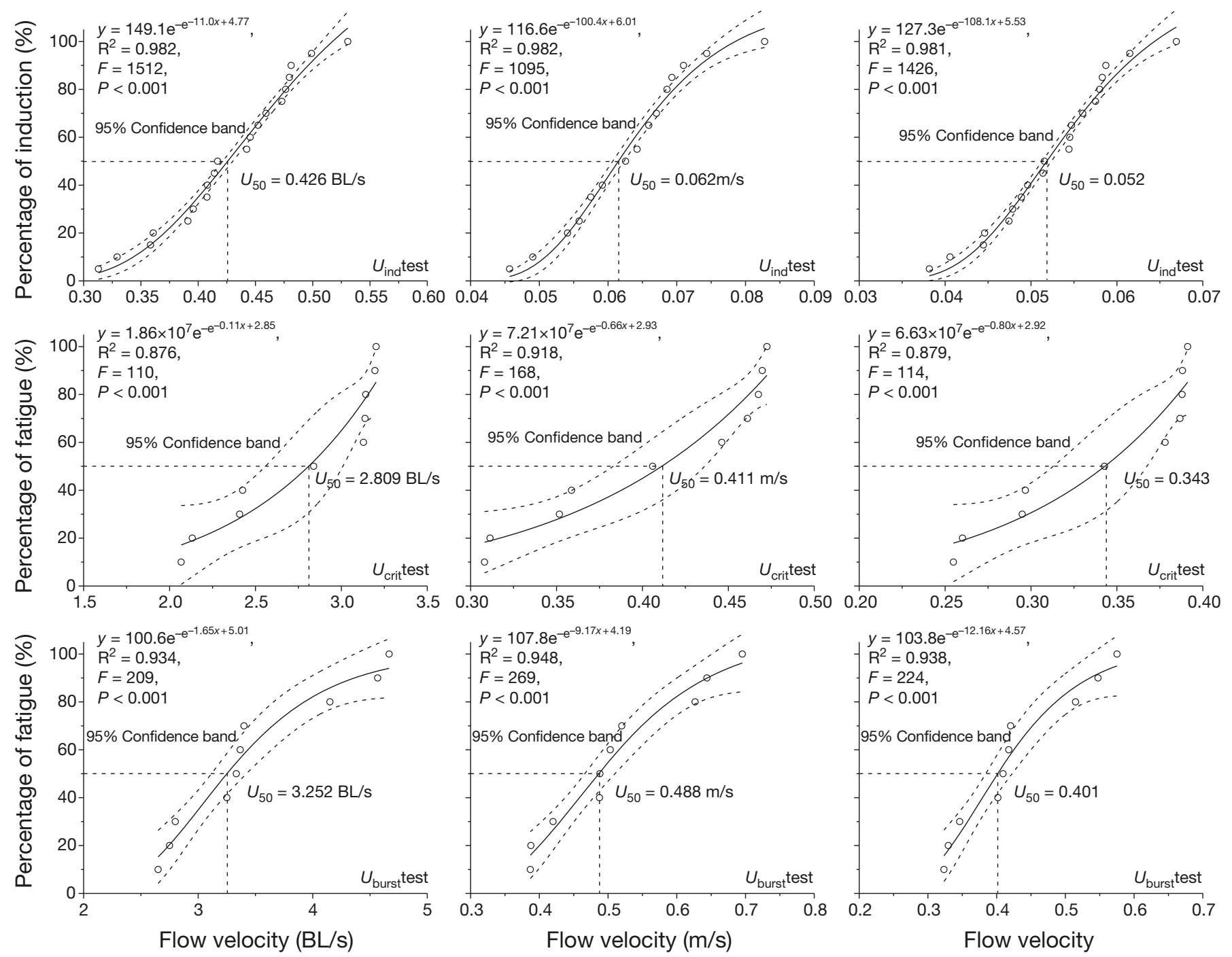

Fig. 1. Percentage of juvenile Cirrhinus mrigala induced to swim and reaching fatigue as flow velocity increased

Table 1. Mean $( \pm \mathrm{SE})$, median and fitted values of swimming ability in Cirrhinus mrigala (body length [BL] 0.147 $\pm 0.001 \mathrm{~m})$ at $15.9-18.7^{\circ} \mathrm{C}(\mathrm{n}$ : number of fish). $U_{\text {ind }}$ : induced flow velocity; $U_{\text {crit }}$ : critical swimming speed; $U_{\text {burst }}$ : burst speed; $U^{*}=U / \sqrt{g \times \mathrm{BL}} ; U$ is $U_{\text {ind }}, U_{\text {crit }}$ and $U_{\text {burst }}\left(\mathrm{m} \mathrm{s}^{-1}\right.$ ), $g$ : acceleration due to gravity $\left(9.81 \mathrm{~m} \mathrm{~s}^{-2}\right) . D_{\mathrm{mm}}=\left(U_{\text {mean }}-U_{\text {median }}\right) / U_{\text {mean }}$ and $D_{\mathrm{m} 50}=\left(U_{\text {mean }}-U_{50}\right) / U_{\text {mean }}, U_{\text {mean }}$ and $U_{\text {median }}$ are the mean and median value of $U_{\text {ind, }}, U_{\text {crit }}$ and $U_{\text {burst, }}$ and $U_{50}$ is the fitted value in Fig. 1

\begin{tabular}{|c|c|c|c|c|c|c|c|c|c|}
\hline & $\begin{array}{c}U_{\text {ind }}\left(\mathrm{BL} \mathrm{s}^{-1}\right) \\
\mathrm{n}=20\end{array}$ & $\begin{array}{c}U_{\text {ind }}\left(\mathrm{m} \mathrm{s}^{-1}\right) \\
\mathrm{n}=20\end{array}$ & $\begin{array}{c}U_{\text {ind }}{ }^{*} \\
\mathrm{n}=20\end{array}$ & $\begin{array}{c}U_{\text {crit }}\left(\mathrm{BL} \mathrm{s}^{-1}\right) \\
\mathrm{n}=10\end{array}$ & $\begin{array}{c}U_{\text {crit }}\left(\mathrm{m} \mathrm{s}^{-1}\right) \\
\mathrm{n}=10\end{array}$ & $\begin{array}{c}U_{\text {crit }}^{*} \\
\mathrm{n}=10\end{array}$ & $\begin{array}{c}U_{\text {burst }}\left(\mathrm{BL} \mathrm{s}^{-1}\right) \\
\mathrm{n}=10\end{array}$ & $\begin{array}{c}U_{\text {burst }}\left(\mathrm{m} \mathrm{s}^{-1}\right) \\
\mathrm{n}=10\end{array}$ & $\begin{array}{l}U_{\text {burst }}{ }^{*} \\
\mathrm{n}=10\end{array}$ \\
\hline Mean & $0.427 \pm 0.013$ & $0.063 \pm 0.002$ & $0.052 \pm 0.002$ & $2.768 \pm 0.146$ & $0.405 \pm 0.021$ & $0.338 \pm 0.018$ & $3.493 \pm 0.121$ & $0.516 \pm 0.034$ & $0.429 \pm 0.028$ \\
\hline Median $\& D_{\mathrm{mm}}$ & $0.430 \&-0.7 \%$ & $0.063 \& 0 \%$ & $0.053 \&-1.9 \%$ & $2.984 \&-7.8 \%$ & $0.426 \&-5.2 \%$ & $0.360 \&-6.5 \%$ & $3.350 \& 4.1 \%$ & $0.496 \& 3.9 \%$ & $0.496 \&-15.6 \%$ \\
\hline Fit $\left(U_{50}\right) \& D_{\mathrm{m} 50}$ & $0.426 \& 0.2 \%$ & $0.062 \& 1.6 \%$ & $0.052 \& 0 \%$ & $2.809 \&-1.5 \%$ & $0.411 \&-1.5 \%$ & $0.343 \&-1.5 \%$ & $3.252 \& 6.9 \%$ & $0.488 \& 5.4 \%$ & $0.401 \&-7.0 \%$ \\
\hline
\end{tabular}

$U_{\text {crit }}$ was $0.45-0.6 \mathrm{~m} \mathrm{~s}^{-1}\left(7-9 \mathrm{BL} \mathrm{s}^{-1}\right)$ (Yan et al. 2012, 2013, Fu et al. 2013), faster than the $U_{\text {crit }}$ measured for C. mrigala (BL $0.147 \mathrm{~m})$ in this study $(0.405 \pm$ $\left.0.021 \mathrm{~m} \mathrm{~s}^{-1}, 2.768 \pm 0.146 \mathrm{BL} \mathrm{s}^{-1}\right)$. The swimming ability of C. mrigala (1 of 4 major Indian carps) is also lower than other Cyprinidae species, including the 4 major Chinese carps, Mylopharyngodon piceus, Ctenopharynodon idellus, Hypophthalmichthys molitrix and Aristichthys nobilis (BL 0.06-0.11 m, $U_{\text {crit }}$ 0.43-1.09 $\mathrm{m} \mathrm{s}^{-1}$; Yan et al. 2013, Cai et al. 2014a). 
Furthermore, the swimming ability of $C$. mrigala is lower than most Cypriniforme species according to the review of Katopodis \& Gervais (2016). During the tests of swimming ability, it was observed that C. mrigala swam by tail oscillation and trunk undulation, which could result in lower swimming ability (Blake 2004). In short, the swimming ability of C. mrigala is relatively low, based on comparison with the species referenced above. Differences in swimming ability have been attributed to differences in morphology and physiology resulting from adaptation to habitat flow regimes (Kieffer 2000, Yan et al. 2013, Crespel et al. 2017). A novel fishway design may be required to accommodate $C$. mrigala as well as species with higher swimming abilities.

We found that $U_{\text {crit }}$ of $C$. mrigala was lower than other carps of similar length (C. carpio, Carassius auratus, S. sinensis, O. sima, Parabramis pekinensis and Ctenopharyngodon idellus; Yan et al. 2012), the ratio of $U_{\text {burst }} / U_{\text {crit }}$ for $C$. mrigala $(\sim 1.2)$ at $\sim 17^{\circ} \mathrm{C}$ is lower than the ratio for these 6 carps $(1.8-2.5)$ at $15-25^{\circ} \mathrm{C}$ (Yan et al. 2012) and other 9 Schizothoracinae (also carps, $1.2-1.8$ ) at $5-20^{\circ} \mathrm{C}$ (Hou et al. 2018), indicating that C. mrigala has more of an ability for sustained swimming than short bursts. We also found that $U_{\text {burst }}$ of $C$. mrigala was lower than other similarsized carp, such as Luciobarbus bocagei and Pesudochondrostoma duriense (Sanz-Ronda et al. 2015). Thus, a fishway for C. mrigala should have a low flow velocity over a longer distance rather than a high flow velocity over a shorter distance.

\section{Reporting data on fish swimming ability and behavior}

In Table 1, the deviations of mean value from median value $\left(D_{\mathrm{mm}}\right)$ and fitted value $\left(D_{\mathrm{m} 50}\right)$ for $U_{\text {ind }}$ $U_{\text {crit }}$ and $U_{\text {burst }}$ were positive and negative, and ranged from 0 to $\sim 15 \%$. The $D_{\mathrm{mm}}$ and $D_{\mathrm{m} 50}$ for $U_{\text {ind }}$ were significantly lower than with $U_{\text {crit }}$ and $U_{\text {burst }}$. This is attributed to small sample size $\left(\mathrm{n}=20\right.$ for $U_{\text {ind, }}$ $\mathrm{n}=10$ for both $U_{\text {crit }}$ and $U_{\text {burst }}$ ) and asymmetrically distributed values. The results of this analysis indicate that reporting several measures of central tendency (e.g. mean, median and fitted values) has merit. Researchers can more effectively examine results on swimming ability and behavior reported by other researchers, particularly when experiments are carried out on a limited number of fish $(n<20)$. Improved reporting of experimental results will allow flow criteria to be set more precisely, improving fishway efficiency.
Acknowledgements. This work was supported by National Nature Science Foundation of China (Grant number: 51609155, 51609157, 51709187).

\section{LITERATURE CITED}

Ahmed I, Khan MA (2004) Dietary lysine requirement of fingerling Indian major carp, Cirrhinus mrigala (Hamilton). Aquaculture 235:499-511

Blake RW (2004) Fish functional design and swimming performance. J Fish Biol 65:1193-1222

* Brett JR (1964) The respiratory metabolism and swimming performance of young sockeye salmon. J Fish Res Board Can 21:1183-1226

*Bett JR (1967) Swimming performance of Sockeye salmon (Oncorhynchus nerka) in relation to fatigue time and temperature. J Fish Res Board Can 24:1731-1741

Cai L, Fang M, Johnson D, Lin S, Tu Z, Liu G, Huang Y (2014a) Interrelationships between feeding, food deprivation and swimming performance in juvenile grass carp. Aquat Biol 20:69-76

Cai L, Liu G, Taupier R, Fang M, Johnson D, Tu Z, Huang Y (2014b) Effect of temperature on swimming performance of juvenile Schizothorax prenanti. Fish Physiol Biochem 40:491-498

Cai L, Wang W, Wang H, Hu W and others (2018) Response of induced flow speed to fish body length and its application in flow design of fish passage facilities. Nongye Gongcheng Xuebao (Beijing) 34:176-181

* Crespel A, Dupont-Prinet A, Bernatchez L, Claireaux G, Tremblay R, Audet C (2017) Divergence in physiological factors affecting swimming performance between anadromous and resident populations of brook charr Salvelinus fontinalis. J Fish Biol 90:2170-2193

Das MK, Hassan MA (2008) Status of fish migration and passes with special reference to India. Central Inland Fisheries Research Institute, Barrackpore

Domenici P, Kapoor BG (2010) Fish locomotion: an eco-ethological perspective. CRC Press, Boca Raton, FL

F Fu C, Cao ZD, Fu SJ (2013) The effects of caudal fin loss and regeneration on the swimming performance of three cyprinid fish species with different swimming capacities. J Exp Biol 216:3164-3174

Grill G, Lehner B, Lumsdon AE, MacDonald G, Zarfl C, Reidy Liemann C (2015) An index-based framework for assessing patterns and trends in river fragmentation and flow regulation by global dams at multiple scales. Environ Res Lett 10:015001

*Gumbine RE, Pandit MK (2013) Threats from India's Himalaya Dams. Science 339:36-37

*Hou Y, Cai L, Wang X, Chen X, Zhu D, Johnson D, Shi X (2018) Swimming performance of 12 Schizothoracinae species from five rivers. J Fish Biol 92:2022-2028

*Katopodis C (2005) Developing a toolkit for fish passage, ecological flow management and fish habitat works. J Hydraul Res 43:451-467

Katopodis C, Gervais R (2016) Fish swimming performance database and analyses. DFO Canadian Science Advisory Secretariat Research Document 2016/002. Fisheries and Oceans Canada, Ottawa

Katopodis C, Williams JG (2012) The development of fish passage research in a historical context. Ecol Eng 48: 8-18

Kieffer JD (2000) Limits to exhaustive exercise in fish. Comp 
Biochem Physiol A Mol Integr Physiol 126:161-179

Kumar P, Jain KK, Sardar P, Jayant M, Tok NC (2018) Effect of dietary synbiotic on growth performance, body composition, digestive enzyme activity and gut microbiota in Cirrhinus mrigala (Ham.) fingerlings. Aquac Nutr 24: 921-929

Nigam AK, Kumari U, Mittal S, Mittal AK (2017) Evaluation of antibacterial activity and innate immune components in skin mucus of Indian major carp, Cirrhinus mrigala. Aquac Res 48:407-418

Palaniappan PL.RM, Karthikeyan S (2009) Bioaccumulation and depuration of chromium in the selected organs and whole body tissues of freshwater fish Cirrhinus mrigala individually and in binary solutions with nickel. J Environ Sci (China) 21:229-236

Pavlov DS (1989) Structures assisting the migrations of nonsalmonid fish: USSR. FAO Fish Tech Pap 308. FAO, Rome

Ravichandran S, Semwal O (2016) Effects of dams and barriers: a mini review. Sri Ramaswami Memorial University, Chennai

Sanz-Ronda FJ, Ruiz-Legazpi J, Bravo-Córdoba FJ, Makrakis S, Castro-Santos T (2015) Sprinting performance of two Iberian fish: Luciobarbus bocagei and Pseudochondrostoma duriense in an open channel flume. Ecol Eng 83:61-70

Silva AT, Lucas MC, Castro-Santos T, Katopodis C and

Editorial responsibility: Victor Benno Meyer-Rochow, Oulu, Finland others (2018) The future of fish passage science, engineering, and practice. Fish Fish 19:340-362

Talwar PK, Jhingran AG (1991) Inland fishes of India and adjacent countries, Vols.1 \& 2. IBH Publishing Company, New Delhi

Tudorache C, Viaenen P, Blust R, Boeck G (2007) Longer flumes increase critical swimming speeds by increasing burst-glide swimming duration in carp Cyprinus carpio, L. J Fish Biol 71:1630-1638

*Wang Y, An R, Li Y (2017) Swimming performance of rock carp Procypris rabaudi and Prenant's schizothoracin Schizothorax prenanti acclimated to total dissolved gas supersaturated water. N Am J Fish Manag 37:1183-1190

*Williams JG, Armstrong G, Katopodis C, Larinier M, Travade F (2012) Thinking like a fish: a key ingredient for development of effective fish passage facilities at river obstructions. River Res Appl 28:407-417

Winger PD, He P, Walsh SJ (1999) Swimming endurance of American plaice (Hippoglossoides platessoides) and its role in fish capture. ICES J Mar Sci 56:252-265

* Yan GJ, He XK, Cao ZD, Fu SJ (2012) The trade-off between steady and unsteady swimming performance in six cyprinids at two temperatures. J Therm Biol 37:424-431

*Yan GJ, He XK, Cao ZD, Fu SJ (2013) An interspecific comparison between morphology and swimming performance in cyprinids. J Evol Biol 26:1802-1815

Submitted: May 7, 2018; Accepted: August 27, 2018

Proofs received from author(s): December 5, 2018 